\title{
Corporate Social Responsibility (CSR) in the Travel Supply Chain: A Literature Review
}

\author{
Eneko Ibarnia $1, *\left(\mathbb{D}\right.$, Lluís Garay ${ }^{2}\left(\mathbb{D}\right.$ and Antonio Guevara ${ }^{3}$ (]) \\ 1 Tourism Department, Deusto University, Universities Avenue, 24, 48007 Bilbao, Spain \\ 2 Economics and Management Department, Open University of Catalonia (UOC), \\ Avinguda Tibidabo, 39, 08035 Barcelona, Spain; lgaray@uoc.edu \\ 3 Faculty of Tourism, Málaga University, León Tolstoy St., Campus de Teatinos, 29071 Malaga, Spain; \\ guevara@uma.es74 \\ * Correspondence: enekoibarnia@uma.es; Tel.: +34-945-200962
}

Received: 13 November 2020; Accepted: 2 December 2020; Published: 4 December 2020

\begin{abstract}
Traditional travel agencies and tour operators are recognized as relevant stakeholders in the tourism distribution chain, even though their role as transforming agents in the achievement of more sustainable tourism is beginning to be accepted. This study aims at reviewing the main topics and the most recent approaches from the academic literature in its analysis of corporate social responsibility (CSR) practices developed by these intermediaries. The work has been structured around six recurring themes in most of the studies carried out: the new intermediaries that operate on the Internet; the role of travel agencies and tour operators in tourism sustainability; the influence of the size of the company; CSR as a disruptive innovation in this sector; the potential of the sustainable tourism supply chain; and the motivations and attitudes of the managers of these businesses when they engage with responsibility. This last topic is developed in greater detail since it is closely linked to the previous ones and dictates, in most cases, the meaning and function of the sustainable performance. The conclusions show how tourism intermediaries have only just begun to develop CSR policies, and those that are committed to their implementation mostly opt for actions aimed at the environment.
\end{abstract}

Keywords: corporate social responsibility; sustainability; travel supply chain; tourism intermediaries; SME; large corporations; motivations

\section{Introduction}

As far as sustainability is concerned, it seems to be the consensus to appreciate it as a balance between economic, socio-cultural and environmental returns and impacts [1]. Concerning the enterprise level, one of the most prolific trends in the analysis of sustainability links it with corporate social responsibility (CSR), understanding sustainability as the ultimate objective of indefinitely maintaining the viability of our economies, the societies in which they are immersed and the environment on which they depend, while CSR refers to business activities, particularly their contribution to achieving this economic, social and environmental sustainability [2]. Although the direct and close relationship of the tourism sector with its physical, economic and social environment is increasingly evident, the research production in the field of tourism and management on CSR is still scarce compared to other sectors [3], even if a soaring interest in it is noticeable [4,5]. It is important to bear in mind that tourism is not a homogeneous productive sector but rather a multisector made up of a great diversity of companies from various sectors-hotels, transport, travel agencies, tour operators, restaurants, activities providers, etc.-with very heterogeneous characteristics, which makes its study and holistic analysis difficult from a traditional microeconomic perspective, usually applied to other economic sectors based on 
the goods they produce. To solve this obstacle, various authors advocate the separate study of these sectors, adapting the research to each of them and with different perspectives [6,7].

This paper aims to explore what has been studied related with CSR about one of the less investigated stakeholders in tourism: intermediaries, and among them, particularly the traditional intermediaries, tour operators and travel agencies. Intermediary tourism companies play a decisive role in promoting and supplying products and assisting in the exchange of information [8], where some of them can shape travel volume and movements, combine and stimulate the thoughts and practices of tourism actors and influence destinations and communities $[9,10]$. The Eurobarometer statistical analyses establish that $20 \%$ of the total travel bookings made by Europeans are contracted in an offline travel agency and that about $15 \%$ of the reserved trips were circuits planned by tour operators. These figures are not only stabilized but even moved upwards in recent years [11]. Besides, the figures are higher if we consider their economic weight, since most of the reservations made through offline intermediaries involve a greater outlay by the consumer in such a way that it is estimated that $30 \%$ of tourism income flows through these intermediaries. In addition, it is also known that in certain countries, such as those in southern Europe or in developing countries, these percentages tend to amount to about 10 percentage points or even more [12]. Consequently, the decision of those intermediaries to become progressively more involved in the use of CSR seems relevant, on the one hand, due to greater consumer awareness and receptivity towards ecologically and socially compatible behaviors [13] and, on the other hand, on account of their central role in the distribution chain. These compelling reasons warrant why it has begun to be considered important that these stakeholders are responsible and focused on the three pillars of sustainable tourism and CSR: the environment, socio-cultural aspects and the economy [14-17].

Additionally, during the last decades, the evolution of information and communication technology (ICT) based on the Internet has questioned the structure of the existing tourism distribution channel and the role played by some of its stakeholders, mainly the traditional firms, leading to new processes, such as reintermediation, disintermediation or hypermediation $[18,19]$. In this context, intermediary companies have made great efforts in innovating their processes and products, in achieving revenue growth and in maintaining or improving their profit margins. However, innovations are often costly and time consuming, requiring considerable investment. In any case, it is understood that the innovation process in tourism intermediation must continue to advance in the use of new tools and, above all, in collaboration between all members of the value chain [20].

For many researchers, CSR must be understood as an innovative key factor for competitiveness and development in all the tourism industry, including its intermediaries [21,22], especially in crisis situations. In contexts of economic and social crisis, business organizations are considered as one of the clues in their overcoming, in particular, given the evolution in society's expectations regarding the role of companies as citizens with obligations [23]. The current COVID-19 crisis has severely impacted the tourism industry but also seems to offer an opportunity of innovation [12]. Therefore, it is not surprising that some authors argue that this pandemic depression may offer an opportunity to rethink and reset tourism towards a better path for the future [24,25] — specifically, for the intermediaries to develop, more than ever, their ability to take advantage of their capacity to add value through their provision of security, guarantee, advice, personalization, proximity and access to proven information, all of them upward values among tourism consumers in the post-COVID era. Reliably, a reconfiguration of the sector is intuited, whether it would be more desirable that it is done by equipping these stakeholders with sustainable strategies and tools than by encouraging CSR. Given its central situation in the tourism market, an analysis turns out to be pertinent as to why and how these enterprises are acquiring their responsibility in the actual crisis.

Based on this context, the following research questions are based on knowing the existing literature and its current status on these issues:

RQ1: What are the main research topics in the study of this subject and on which aspects do they focus their studies? 
RQ2: Are these stakeholders taken into account by researchers in the ultimate goal of achieving more sustainable tourism?

\section{Corporate Social Responsibility in the Tourism Industry}

Tourism is, perhaps, the industry that shows the most significant growth rates, in relation to the contribution to the GDP and employment of people of many countries. It involves both benefits and tensions and conflicts [26], which is why it is key to mitigate the negative repercussions that occur in it, not only for the good of the environment and the society but also for the survival of the industry itself [27]. In this sense, although the relationship between tourism and sustainability has been extensively outlined [28], the same has not happened with the approaches of the tourism industry to the challenges of this sustainability. Nevertheless, there is a general agreement that the answer in this analysis of the tourism companies must be given by CSR [29].

Due to the comparatively recent pursuit of this field, there are still no clear standards on how to implement CSR in firms related to tourism activity $[29,30]$. Studies continually present inconclusive or contradictory findings regarding the financial impact [31], often with meaningless CSR reports [32] and causing consumer cynicism about proposals perceived as a facelift [33]. The problem derives from the same definition of what CSR is or should be in the tourism sector, indistinctly applying the numerous definitions of the term existing in the generalist literature, as well as its models and indicators, which denotes a lack of critical conceptualization for the sector, especially because its own peculiarities are not taken into account [30].

Overall, the hotel sector monopolizes most of the analyses carried out to date, followed far behind by aviation [34]. Therefore, the rest of the tourism sectors are relegated to sporadic studies, although with an increasing presence in the literature $[5,17]$. Likewise, the research on CSR in tourism is focused, for the most part, on certain aspects, such as environmental measures or the communication of undertaken actions [35], and not on a comprehensive application of the concept in the sector [36]. From a review of the state of the art, it can be deduced that the actions carried out in CSR are mainly focused on the environmental dimension [31,37-39], with little disclosure of these policies [40], where those aspects that reduce costs and have repercussions in economic profitability, such as saving water or energy efficiency, are predominant [41].

Given the predominance of environmental issues, a large part of the published studies has been focused on the impacts produced by the tourism industry and on the creation and development of sustainability indicators for their management and control. In this line, several studies assess the use of energy in the sector and advances in the commitment to the use of renewables, as well as the reduction in waste generation and water consumption [42]. To a lesser extent, although increasing in recent years, researchers' agendas have been incorporating topics such as technology for sustainability [38], stakeholders participation [5], gender equality [43], business ethics [44,45], tourism in favor of poverty alleviation [46], certifications of sustainability [47], marketing [48], consumer perceptions [49,50] or the perspectives and intentions of employees [51]. Meanwhile, there is a growing academic interest in topics such as the role of the industry in promoting the sustainable consumption of tourism, opportunities in the face of changing social habits, sustainable industry-tourist communication or the motivations and sustainable behaviors of entrepreneurs [42].

\section{Corporate Social Responsibility in the Travel Supply Chain}

\subsection{Research Methods and Process}

This paper consists of a systematic literature review (SLR) about CSR research among tourist intermediaries, especially tour operators and travel agencies. Organized, transparent and replicable procedures were employed in this SLR, as recommended in the literature [52], and were carried out in three stages: planning the review; conducting the review; and reporting and dissemination [53]. Table 1 presents a summary of the main activities conducted in each stage. In the first stage, 
an exploratory literature overview of the main related constructs was conducted, such as corporate social responsibility, sustainability, tourism intermediaries, travel agencies, tour operators and travel supply chain. This was conducted in a non-structured way to build an initial perception of the research field, based on snowball logic (accessing references of references) and trial-and-error (testing combinations of keywords for filters in paper databases). An important result of this stage is the preliminary version of the research question. Another result is the definition of criteria for the filters used for the paper sample. This definition is crucial for the research since it determines the quality of the results.

Table 1. Stages of research.

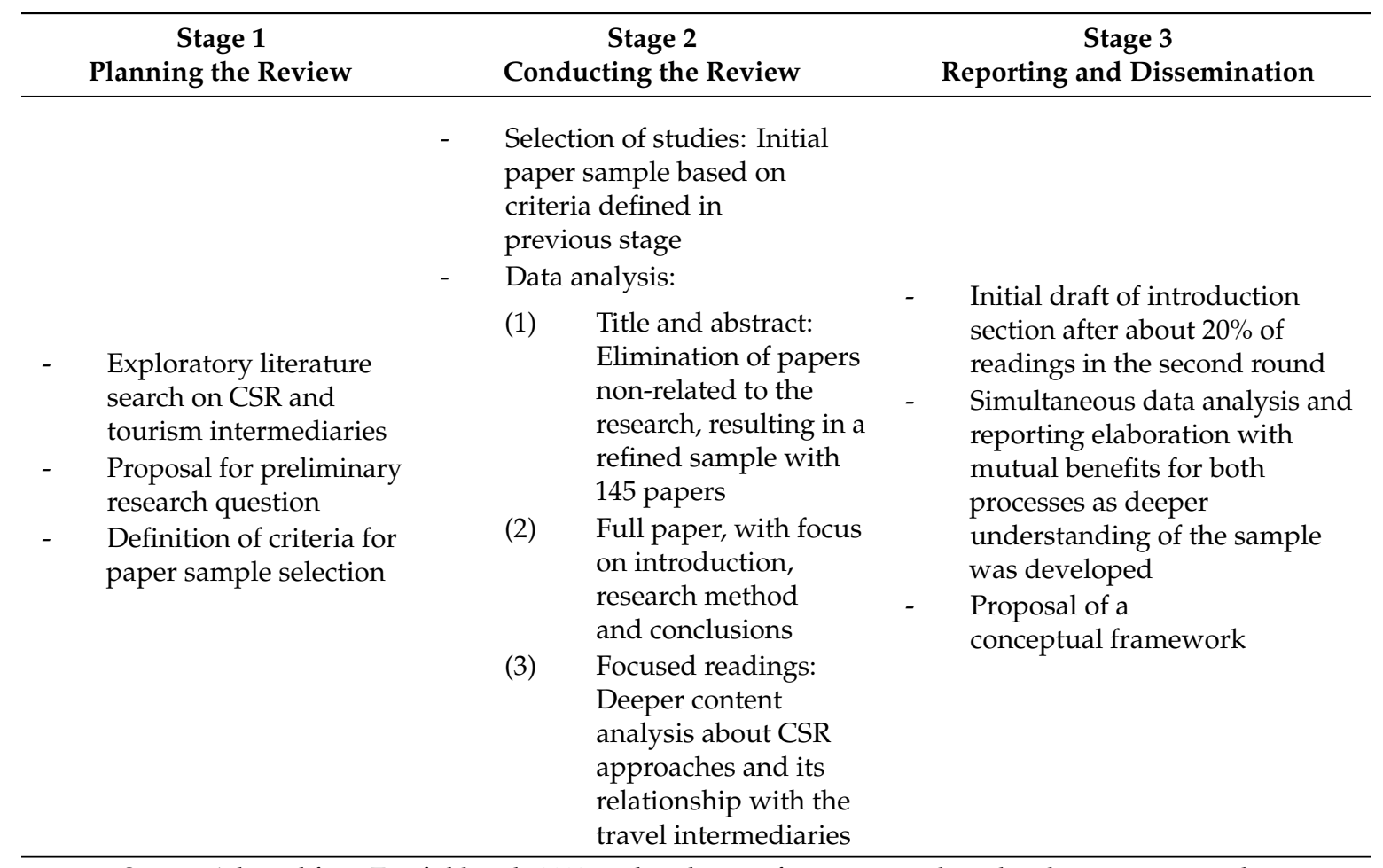

Source: Adapted from Tranfield et al., 2003, with inclusion of activities conducted in the present research.

The second stage represents the review itself [53], which was initiated with the data collection. For this step, a collection of articles on CSR and travel supply chain was obtained by querying the Institute for Scientific Information (ISI) Web of Knowledge (Web of Science) and Scopus databases, seeking research publications in the period between the years 2000 and 2020. These databases were chosen given their comprehensiveness of papers, including titles from Emerald, Elsevier, Springer, Willey, Taylor and Francis and JStor, among others. The following filters were used: (1) in the title: Corporate Social Responsibility or CSR or sustainability; (2) in the title or keyword or abstract: travel agenc* OR tour operator* OR travel supply chain* OR tourism supply chain* OR travel distribution* OR tourism distribution OR travel intermediat* OR tourism intermediat*. The symbol (*) has the function to include any variation on the terms searched. The first reading of the papers was restricted to title and abstract, with the objective of excluding papers without adherence to the present research and without the available full paper. The final sample consists of 145 papers.

Data analysis was initiated with the second round of readings, which included the full text, with a focus on introduction, research method and conclusion sections. In this step of data analysis, a brief description of the content related to CSR and its relationship with the travel intermediaries was made, and the main studied topics were extracted. When references used by the papers of the sample contributed to the discussion of results, they were also included to support the data analysis. The third stage of the research, the dissemination [53], was conducted simultaneously with the data analysis. 


\subsection{Results: Main Academical Discussions}

After an exhaustive reading of the existing literature, six topics were considered the most studied or relevant: (a) the role of tourism intermediaries towards sustainability; (b) the firms' size factor; (c) online intermediaries' commitment; (d) the use of the CSR as an innovative strategy; (e) the sustainable tourism supply chain; (f) and the behavior and motivations of the managers facing CSR. In order to confirm the relevancy of these topics, a content study was carried out with the qualitative analysis software Nvivo, which analyzed the 500 most-mentioned words in all the articles, manually excluding the connecting words (prepositions, etc.) (see Figure 1). The results of this test offer clear coincidences with the assessments obtained from the reading of the articles, where words such as product, sustainability, operators, impact or consumer(s) (topic a), large, small, local or brand (topic b), online, media, global or Internet (topic c), innovation, future, quality, change, process (topic d), value, supply, community, suppliers (topic e) and behavior (topic f) confirm the relevance of the issues.

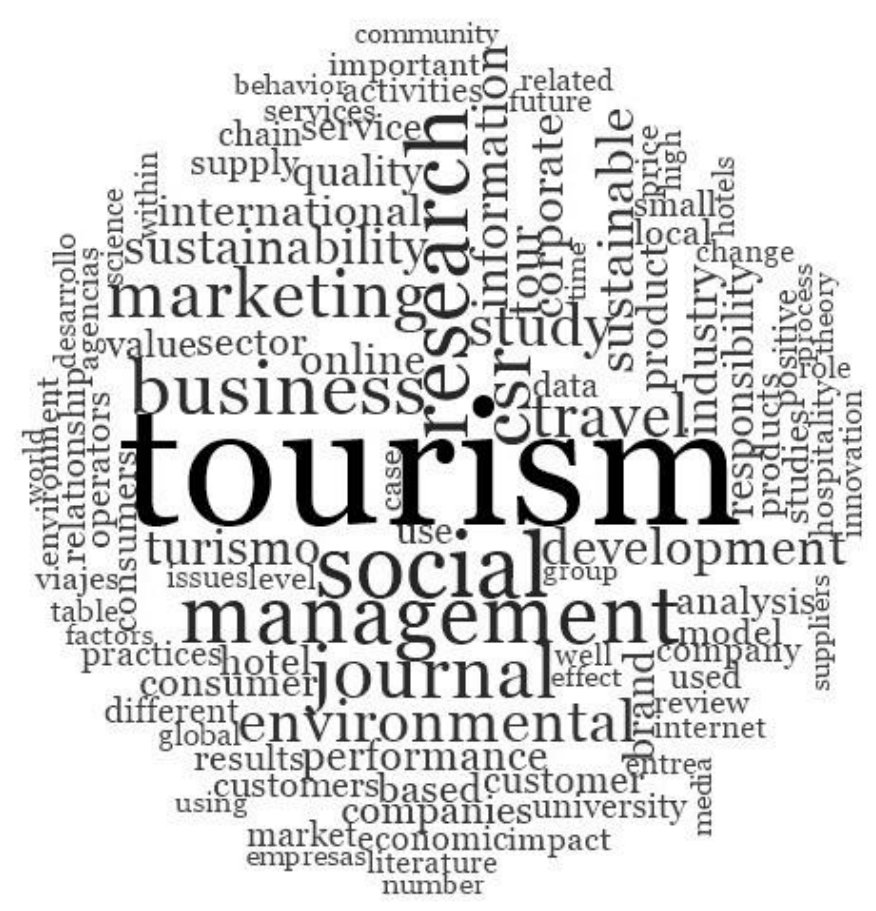

Figure 1. Cloud of concepts with the most-mentioned words in the articles.

As noted, CSR studies in tourism have focused mostly on hotels and mainly on environmental elements rather than on intermediaries [14], despite the fact that these companies are key players in the tourism industry. Notwithstanding the tough competition due to the eruption of ICT and the Internet, the evolution of the tourism industry has consolidated travel intermediaries in recent decades [54]. Nowadays, not only do the traditional offline intermediaries and the online intermediaries live together in the tourism distribution channel, but each one takes advantage of their comparative assets and their market niches [55]. The review of the research in the field of CSR among these stakeholders, whatever the distribution channel is, reflects an imbalance between online and offline intermediaries' studies, where traditional actors almost comprise all the weight of the literature, revealing a gap in the knowledge of how the commitment of online intermediaries with CSR is. Nonetheless, an incipient interest is emerging in the academy, trying to analyze this emptiness (see Table 2).

One of the main investigation lines followed by the research involves the role and possibilities that the intermediaries have (or should have) confronted the challenges of CSR, including the dealt barriers and the accomplished actions, as well as accepting and acknowledging their central role in sustainability $[9,10]$. Generally, the major outbound tourism market structures are configured 
with a few large tour operators and travel agency groups, who control a high percentage of these markets, and a large group of small and medium enterprises (SMEs), who try to survive them through product and quality differentiation [56,57]. Many studies have focused on the different approaches that companies perform in their approach to CSR, depending on their size. With that in mind, aligned with what happens in other well-studied sectors, the differentiating factors for large companies were based on the nature of their structure and objectives, and for SMEs, on their underlying motivations [58].

Table 2. Main discussions about CSR and tourism intermediaries.

\begin{tabular}{|c|c|}
\hline Discussion & Author(s) \\
\hline $\begin{array}{l}\text { The role of tour operators and travel } \\
\text { agencies in sustainability }\end{array}$ & $\begin{array}{l}\text { Khairat and Maher [9]; Sigala [10]; Lund-Durlacher [13]; } \\
\text { Schwartz et al. [54]; Zapata et al. [59]; Richards and Font [60]; } \\
\text { Tigu et al. [61]; Budeanu [62]; Goodwin [63]; Font et al. [64]; } \\
\text { Villarino and Font [65]; Dolnicar, and Laesser [66]; } \\
\text { McKercher et al. [67]; Chen and Peng [68]; Alonso et al. [69]; } \\
\text { Xin and Chan [70]; Jenkins [71]; Chubchuwong [72] }\end{array}$ \\
\hline The firms' size factor & $\begin{array}{c}\text { Sigala, [10]; Anderson et al. [47]; Udayasankar [58]; } \\
\text { Zapata el al. [59]; Garay et al. [73]; Van Wijk and Persoon [74]; } \\
\text { Norbit et al. [75]; Garay et al. [76]; Tapper [77]; Carey et al. [78]; } \\
\text { Kilipiris and Zardava [79]; Budeanu [80]; Clarke [81]; } \\
\text { Salvado [82];Russo and Tencati [83]; Sardianou et al. [84] }\end{array}$ \\
\hline Online intermediaries' commitment & $\begin{array}{c}\text { Coles et al. [17]; Salvado [82]; Panda and Modak [85]; } \\
\text { He et al. [86]; Chunjou and Pang [87]; Lozano [88]; } \\
\text { Dube and Nhamo [89] }\end{array}$ \\
\hline CSR as an innovative strategy & $\begin{array}{c}\text { Camisón and Monfort-Mir [21]; Mei et al. [22] } \\
\text { Richards and Font [60]; Chubchuwong [72]; Alonso et al. [90]; } \\
\text { Ioncică et al. [91]; Ko et al. [92]; Kraesgenberg et al. [93]; } \\
\text { Balaguer [94]; Thomas et al. [95]; Almunawar et al. [96]; } \\
\text { Mourshed et al. [97]; Alegre and Sard [98]; Chapuis [99]; } \\
\text { Huët [100]; Baniya et al. [101] }\end{array}$ \\
\hline The sustainable tourism supply chain & $\begin{array}{c}\text { Sigala [10]; Peña et al. [27]; Zapata et al. [59]; } \\
\text { Richards and Font [60]; Salvado [82]; Panda and Modak [85]; } \\
\text { Xu and Gursoy [102]; Mwesiumo and Halpern [103]; } \\
\text { Tsaur et al. [104]; Baddeley and Font [105]; Allen et al. [106]; } \\
\text { Brockhaus et al. [107]; Font et al. [108]; Kwon and Suh [109]; } \\
\text { Piboonrungroj and Disney [110] }\end{array}$ \\
\hline Management behavior and motivations & $\begin{array}{c}\text { Lin et al. [14]; Alonso et al. [69]; Garay et al. [73]; } \\
\text { Sardianou et al. [84]; Tsaur et al. [104]; Cheng et al. [111]; } \\
\text { Okech [112]; Font et al. [113]; Goffi et al. [114]; } \\
\text { Atanase and Schileru [115]; Wong and Lee [116]; Erdogan [117]; } \\
\text { Mossaz and Coghlan [118] }\end{array}$ \\
\hline
\end{tabular}

In addition, as indicated above, those traditional intermediaries that operated in the 1990s have taken advantage of the Internet and ICTs in recent decades to survive, where their main concern has been how to adopt and assimilate these innovations to obtain and maintain a competitive advantage $[119,120]$. Similarly, the adoption of CSR has been studied from its link with the innovation and these companies' proven capacity for embracing it. Thus, intermediary managers can take advantage in change scenarios to use their CSR initiatives in an innovative way [90]. This can be induced through the design of strategies and the formulation of new forms of work, which, in other sectors, have led many companies to redefine their business models [121]. Undoubtedly, one of the most prolific fields of research between CSR and intermediaries has been to gain a clearer understanding of the specific sustainable requirements, opportunities and constraints at each point in the tourism supply chain in order to identify common success criteria, barriers and opportunities to sell more responsible tourism [102]. Furthermore, travel intermediaries have the ability to influence travelers' choices, other supply chain member strategies and destination development plans, so it has seemed to be useful in the 
understanding of their contribution to the sustainable tourism supply chain through CSR [59]. Finally, a last and very prolific line of research has identified a series of managers' motivations that may lead them to adopt CSR, all of them in accordance with the motivations set out for the industry in general and the tourism sector in particular $[14,73,111]$. Typically, these motives include responding to stakeholder pressure, gaining a competitive advantage, adhering to government regulations, avoiding fines and other regulatory actions and improving their image. In addition, managers may also have internal ethical values to guide business decisions. This may involve a responsible conscience that prompts owners and managers to do "the right thing" [47].

\subsection{The Role of Travel Agencies and Tour Operators toward Sustainability}

The literature indicates that in recent years, there has been a nascent trend among tourism intermediaries to be increasingly involved in the implementation of CSR measures, precisely due to the growing awareness and sensitivity of consumers towards ecological and social behavior. These tourism actors face extraordinary challenges when implementing CSR in their businesses as they not only have to evaluate CSR measures within their own company but also throughout the value chain [13]. The development of CSR in this subsector of the tourism industry has particularly responded to issues related to the promotion of sustainable tourism practices, with very few initiatives for full integration of responsible policies in organizations. Although interest in responsible tourism is high and currently a recurring debated topic, it is not very widespread among intermediaries, and coherence in CSR policies, programs and practices is still sought [61], so much so that the factors that shape the adoption of sustainability practices by intermediaries show how sustainability strategies, practices and standards seem to be conceived primarily as a means of risk management (to prevent a negative public image), as a competitive advantage (brand equity and reputation) and as a strategy to manage regulation [54] rather than as a means to provide better customer services, cost savings or business opportunities [62]. Research suggests that the incorporation of intermediary companies in a process of setting the CSR agenda is primarily a response to customer concerns, non-governmental organizations (NGO) activities or due to negative publicity from their activities [59].

There seems to be an agreement that among intermediaries, a relevant part of their conception of what is responsible is directly related to the need to source and sell more sustainable products. Yet, despite growing product offerings, supported by apparently strong business cases, sustainable tourism still accounts for only a remarkably small proportion of the total tourism supply [63], with a sense of lost opportunities and low involvement faced with a demand for distinctive and sustainable experiences without translation into additional sales [60]. In this sense, it is known that tourism companies that integrate sustainable practices tend to find it difficult to effectively communicate their commitment to sustainability and the derived benefits for the client $[64,65]$. Nevertheless, there is little evidence to support these companies in communicating their sustainable actions in a more persuasive way, although some studies have provided evidence in this direction [122,123].

Hence, travel intermediaries must also play the role of information intermediaries, or professional infomediaries [66], particularly when exclusive and specialized experiences are involved. Consequently, they can have significant power to shape the relationship between tourism products and services and tourists themselves, preferentially selling and targeting some of them in particular. Despite this, little research has been conducted on their role as potential responsible tourism actors, although there are studies that demonstrate a resistance of the subsector to understand and integrate the concept of sustainable tourism [67]. More specifically, little is known about their role in developing ethical considerations in sustainable tourism supply chains that ultimately shape the development of this sector [68], although studies have outlined the relevant fields of action for the development of a correct CSR policy within these companies: the internal management, the product development, the supply chain, the customer relations and the cooperation with the destinations [9]. 


\subsection{The Firm's Size Factor}

When the literature related to sustainability has made reference to a subsector as relevant as this, it has focused especially on large international tour operators, generally ignoring travel agencies [76], which are not only basic in the sectoral structure of most international destinations but are also leading major transformations in the sector, both in disintermediation and reintermediation processes $[19,124]$. This uneven analysis can be extrapolated to each stakeholder separately; thus, tour operators have been mainly studied by large corporations, while travel agencies have a priority focus on SMEs [59,73]. Early studies highlighted the disparity of business approaches in this regard, depending on small, medium and large companies [77]. In CSR performance, although worse than in other tourism subsectors, large firms were more advanced than medium and small ones, while medium-sized companies, in turn, performed better than small companies [74]. In contrast, previous pioneering research already showed that small-scale specialized intermediaries were more interested in protecting the environment and tended to be more active, encouraging policymakers at destinations to develop viable long-term strategies [78].

The latest studies have delved into the different performances between SMEs and large companies when CSR is concerned. In fact, among large corporations, given how their priorities are established, the main practices towards CSR are internal policies that are oriented with codes of conduct and certification systems that serve as marketing tools [59]. On the contrary, those who stand out for their CSR practices and policies are the smaller organizations $[76,79,125]$, which emphasizes that having small operations can be a success factor for the development of sustainable tourism [126], implicitly excluding the possibility that large organizations can adopt it. While examples of responsible small-scale practices flourish, the lack of empirical evidence in mass tourism suggests that charitable actions, the adoption of codes of conduct and environmental measures are applicable improvements for large-scale operations [127], expanding its conceptual dissociation from sustainable tourism. The limited adoption of sustainable product development procedures by large companies indicates the possible existence of deeper organizational barriers, causing only a few large intermediaries to have formal sustainable product development procedures, sometimes justified by their managers' unfamiliarity with the concept of CSR or the erroneous idea that it is not a profitable product for them if not for smaller companies [62].

As Budeanu indicated [80], large companies and their own retail subsidiaries were the first to adopt a more proactive attitude and who have begun to develop responsible policies and plans in recent years. However, the viability of their structural adjustment has proven to be very low since most of these groups are not innovative enough in this field to consider it in all its breadth and to be able to face the presumed expenses and investments that it would entail [81]. The other two models of tourism intermediaries linked to large networks, franchisees and associates, have little place in tourism research, much less in specific topics, such as CSR, with few exceptions in which these two models are analyzed as a brand of the large companies with which they are related, without taking into account their own characteristics and specificities [82].

As in the rest of the tourism sector, in the specific case of SME intermediary companies, they do not usually have complex management structures and are generally managed by their owners, oriented towards solving the day-to-day business, establishing informal and close relationships with their interest groups and living in a reality dependent on the dynamics of the sector, determined, on many occasions, by the actions of larger companies [83]. These largely independent small-scale companies position their value propositions [128] through their presence on the Internet to reinforce their differential factors, including sustainability, making ICT a basic element of tourism marketing [129]. The perception within these travel agencies in this matter is coincident and they think that their possibility of sustainable actions is limited within the sector as a whole. They adduce how the size of the company can be a determining factor but warn that they can become decisive in this area, particularly with regard to its environmental aspect. Consequently, they have to improve their 
knowledge and information in this regard, at the same time that a more active role from agency/tour operator associations and the management groups to which they belong is indispensable.

Small- and medium-sized tour operators can respond to their own challenges through CSR, although their proposals are often reduced to suit their own capabilities [75]. This happens because typically, most are too focused on short-term goals to maximize profits, with a penchant for being tactical in their strategy, with their primary focus on customers who are their direct source of immediate information and short-term income, secondarily considering other objectives, such as competitive advantage, branding, etc. Consequently, economic subsistence is the first and foremost goal among tourism intermediaries, regardless of size [130]. Along these lines, there is an academic discussion which sustains that the size of the tourism intermediary company does not seem to be related to the desire to develop responsible practices, since the vast majority of the managers report receptivity towards more sustainable models. This development would seem to be related to price, where companies for which this is the most important factor would be less willing to bet on CSR, while those that attach greater importance to responsible practices, even taking price into account, show a higher interest and knowledge of CSR, which makes them more inclined to implement it [47].

\subsection{Online Intermediaries' Commitment}

Given their prominent role in the present society, online intermediaries are increasingly expected to act according to current social and cultural values, which raises questions as to what kind of responsibilities they should bear and which ethical principles should guide their actions [131]. There is a largely specialized literature that has studied the implications of online distribution in the tourism supply chain, mainly attending to cost, price and service level [132,133], on the effects on traditional intermediaries $[57,134-136]$ and on the trust and quality achieved by the companies operating in this channel $[137,138]$. In contrast, few studies have analyzed the development of CSR in online tourism intermediaries $[17,82,85]$, but findings show that the acceptance of the new channel by consumers and the cost advantage it brings to these intermediaries, together with the profit sharing rate and the distributor's CSR behavior, jointly influence the choice of the sales channel and prices, showing that CSR behavior of online intermediaries could benefit the tourism supply chain and a greater acceptance of this channel among tourists [86].

The few research studies that have been published on online intermediaries and their responsibilities have followed the general trend of the sector of an environmental approach, prioritizing the websites of these intermediaries as relevant in attracting consumers to low-carbon trips. In other words, the web would not only provide travel information resources for tourists but would also motivate them to participate in more responsible travel [87]. These authors indicate that environmentally responsible travel promotions can hardly be found, concluding that online wholesale and retail travel agencies have not been generically implementing actions related to CSR. In addition, these few research studies have basically focused on the case of large tour operators [88], paying marginal attention to the case of retailers.

However, one of the most notable aspects in tourism intermediation regarding online marketing, as researchers have pointed out, is the transition of traditional companies to the online world, combining both sales channels, a clear example of the resilience of this subsector. Most of them have been digitized by using e-marketing to reach customers instead of printing brochures, which come with a considerable amount of greenhouse gas emissions. In this sense, almost all intermediaries use various online platforms to communicate with customers, ranging from Facebook, Twitter and YouTube to blogs, websites and other web-based applications, instead of traditional marketing methods, thereby increasing their market share [89].

\subsection{CSR as an Innovative Strategy}

There is unanimity among academics that innovations represent a key factor for competitiveness and development in all areas of activity, including the tourism industry and its intermediaries [21,22]. 
On the contrary, there is no such consensus regarding the contents and typology of innovations in the tourism intermediation sector since, traditionally, these have been associated with the need to identify and solve technical problems. Another important and controversial problem from the point of view of innovation research in the activity of intermediation agencies is related to the link between innovation and the size of the company [91], an aspect that would influence the sale of sustainable tourism products and its impact on the efficiency of the activity of intermediaries and their responsibility, according to the latter authors. Many researchers affirm that innovation is associated with an entrepreneurial spirit characteristic, mainly of new companies of small dimensions, which is why it is suggested that the innovative activities of SMEs are the most important determinant of their success [92]. On the other hand, large companies maintain the advantages that their size gives them to support the commercial development of new ideas by having the necessary financial resources to carry out experiments and prototypes or pilot operations.

Although CSR is not the panacea or the only measure to ensure the success of a business, even in crisis outlooks, the literature shows that many of the actions that are proposed to overcome the challenges are derived from the innovative conception of CSR and are directly related to factors that are integrated into the responsibility of the companies [93]. Above all, they have a lot to do with investment and innovation strategies that allow the integration of analysis criteria based on the sustainability of companies, with strict accountability measures, and on regulated business transparency frameworks, with the analysis of social and environmental impacts integrated in the risk management, and, finally, with the adoption of responsible structures for corporate governance and independent and external supervision [94]. As a result, the access to knowledge and innovation increases their capacity for internationalization, reduces their costs, increases their competitiveness and encourages the creation of work and support networks [95].

Moreover, unlike a few decades ago, tourists demand innovation in services and products, a requirement that must be adequately answered by intermediaries, which requires sustainable innovation, both in the development of processes and in products, to achieve sustainability in business [96]. To meet this demand and promote sustainability, the exchange of information is considered necessary in order to reduce inefficiency and waste of resources [97]. However, sustainability is not just about innovation and technology adoption but also about taking customer behavior into account when offering more sustainable products or services. Nevertheless, studies coincide in highlighting that the adoption of responsible practices and innovations by tourism intermediaries seems to go relatively unnoticed by their customers

It is a fact that many tourism intermediaries operate with small profit margins, and the resulting pressure from suppliers to lower prices may limit their ability to invest in quality improvements and innovations or other strategies that do not have a relatively immediate return [98]. However, there is a vanguard of companies that understand the concept of CSR innovation as applicable to their business initiatives, creating a de facto specific market niche, which consider social awareness work and offer services aimed at changing social practices of the trip [99], appealing to both individual and collective responsibility. For these, the responsible tourism middleman must be exemplary, with everything and everyone. Its responsible policies list evidence of its good behavior with the environment (use of recycled paper, free software, etc.), with its employees (reconciliation of work and family life, fair wages, etc.), with travelers, with the rest of the companies in the sector and with the destination and its population. Its credibility is based on the manifestation of a close commitment to responsible tourism [100].

\subsection{The Sustainable Tourism Supply Chain}

The study of the sustainable supply chain in tourism has focused mainly on understanding the adoption of sustainability governance mechanisms $[59,80,139]$ and on resource efficiency and cost savings [10,105]. Other lines of research have also exposed the exercise of power and unequal control over providers by tour operators $[140,141]$. In this sense, some authors point out several fields in which 
a more detailed analysis of CSR in the tourism supply chain would be beneficial, such as the role of different actors in the sustainable supply chain $[60,103,142]$, or, to obtain a clearer understanding of the specific sustainability requirements, opportunities and limitations at each point of the tourism supply chain $[102,143]$. However, a very important factor not sufficiently recognized in the tourism literature is the complex set of corporate and contractual international agreements that characterize tourism intermediators, a factor that adds difficulties in achieving a sustainable supply chain since it is difficult to verify the commitment to CSR of each and every one of the companies with which it collaborates [59]. The problems and difficulties in persuading external contractors and small tourism providers to jointly commit to CSR are also emphasized. Given the large number of SMEs, as well as their importance for the socioeconomic viability of many destinations, studies that investigate how to overcome these troubles and support these SMEs in their commitment to sustainability are noted to be essential [10].

Similar conclusions are reached by other researchers who highlight how tourism intermediaries have limited potential to achieve sustainable management of the supply chain, caused by a lack of understanding of sustainability by their managers, a lack of values at the company level with respect to sustainability, budget constraints, supply chain conflicts, a lack of personnel trained in sustainability and a lack of planning [102]. On the contrary, it seems undeniable that the relationship between the two traditional travel agency models, tour operators and travel agencies, is aimed at mutual collaboration and associationism, where the ideal would be a useful relationship in which both companies could create added value, share information and increase market opportunities [104]. These authors suggest that interpersonal behavior in their relationships, the offer of support and the mutual search for customer satisfaction motivate managers to increase the quality of the relationship between travel wholesalers and retailers, where the duration of the relationship and importance of the product would affect this relational behavior.

Therefore, a supportive organizational culture is a prerequisite for the success of companies that want to increase the volume of sustainable products that they source and sell. Sustainability is only sold when it contributes to an organization's ability to meet its service quality requirements, especially in relation to the suitability of products for its target markets and the strengthening of professional and trustworthy relationships. Business-to-business marketing requires suppliers to understand the relative importance of sustainability to each of their providers and, in response, develop appropriate arguments to explain the importance of sustainability within the organizational needs of their buyers [60]. In this sense, the literature underscores the lessons to be learned from tourism supply chain research on how tour operators and local suppliers can collaborate effectively to foster sustainable tourism. Based on the literature review in this regard [54,102,105-110], these lessons can be grouped into six areas: (a) collaborative visions that include well-coordinated communication (including shared values), exchange and joint planning of information, "socialization" (for example, meetings, conferences or visits to the destination) and establishment of cross-functional teams to maximize opportunities for information transfer and collaboration related to sustainability; (b) training and advice, including awareness-raising interventions, targeted training, well-designed sustainability manuals and support for internal auditing, certification, monitoring and reporting; (c) contractual and procurement incentives, including preferred partner status, fair purchase and contractual conditions; (d) financial support, including soft loans; (e) rewards and incentives; (f) and promotional opportunities.

\subsection{Management Behavior and Motivations}

In their role as intermediaries for tourism consumption, the perceptions, opinions, beliefs, attitudes and work practices of these stakeholders make important contributions, negative and positive, to the sustainable development of tourism. Despite this, studies on tourism intermediaries and managers are fairly recent and limited in quantity and quality, especially in the non-Western world. In this subsector, the degree of behavior based on opinions and attitudes in daily business practices is barely known since the structural environment of economic and political decision-making is marked by personal and 
organizational objectives, power relations and dominance. There are numerous variables, internal and external, that intervene in the form of an adequate and improved CSR performance when translating their responsible attitudes and principles into concrete operational changes [117].

In the same way as other sectors, motivations and responsible behaviors tend to differ notably between large companies' and SMEs' intermediaries, and even the behavior of managers of smalland medium-sized companies with regard to CSR is far from being homogeneous [73]. In large corporations. there are usually coercive and regulatory pressures from the top down, so the managers of the delegations and sales offices have little room to maneuver and implement their own CSR initiatives, although there may be lines of business that are not passive recipients of these pressures and small responsible practices can be carried out outside the institutional guidelines [59].

In SMEs, on the other hand, the difficulties have been considered more than the advantages when it comes to introducing CSR, although the literature is modifying this vision. As a rule, the lack of resources [144] or information about market requirements and the opportunities for change related to these practices [145] are recurrent in most discussions. Researchers also point out the existence of differences between large tourism companies and SMEs, which are sometimes key for the development of CSR policies, especially in economic, financial and information resources [146]. These academic contributions also tend to refer to the strengths of SMEs, such as the advantage of reacting more quickly and flexibly to certain aspects (including those related to CSR) and the closer relationship with their stakeholders [71]. In addition, in this business model, decision-making in this regard results, in many cases, in an extension of the owner's personality [147], and in the case of entrepreneurs, this can be decisive to stimulate a responsible culture and to ensure that it is related to values other than profit maximization as the sole criterion [126]. These considerations justify the fact that in the context of smalland medium-sized intermediate firms, a wide degree of divergence is observed in the introduction of responsibility practices, depending on the different company profiles [76].

Finally, several of these studies have identified a series of managers' motivations that may lead them to adopt CSR, all of them in accordance with the motivations set out for the industry in general and the tourism sector in particular $[14,73,111]$. These typically include responding to stakeholder pressure, gaining a competitive advantage, adhering to government regulations, avoiding fines and other regulatory actions and improving their image. Moreover, managers may also have internal ethical values to guide business decisions. This may involve a responsible conscience that prompts owners and managers to do "the right thing" [49].

\subsubsection{The Business Case}

A first type or category of intermediary is described with a markedly opportunistic profile and is aimed at gaining market share with sustainability. These companies, normally large groups and also some medium-sized ones, have a high technological capacity and introduce sustainability as a market strategy and "image washing", so their mission, in relation to sustainability, responds more to the achievement of finalist objectives than to a certain vision of the world [76]. When addressing the motivations underlying their adoption of CSR, improving the company's image is considered the most important factor [54], followed by public relations, both motivations related to marketing programs. In fact, the construction of a positive public image is the most important motivator that drives large intermediary companies to adopt more responsible strategies, even more than responding to the demand of customers, which ranks second [9]. Therefore, a greater commitment to CSR for instrumental reasons can be expected from larger and more structured corporations than from SMEs [114].

The implementation of CSR programs for the managers of these firms is supported by an expected direct, positive and significant impact on the financial results of the company [148]. Any practice that improves the performance and business competitiveness of these businesses (image, customer satisfaction, employee satisfaction, etc.) has a positive impact on the company's results [149-153]. This relationship of CSR with results and competitiveness is relevant and motivating 
for these managers and has proven proactivity in sectors, especially those affected by crises and in which there is a continuous movement, such as in tourism intermediation [154]. The presumed competitive advantage, tax advantages, fashion, mandatory compliance from the parent company or external pressure (media, NGO, public, government, etc.) are, consequently, additional motivations highlighted by the existing literature [61].

\subsubsection{The Stakeholders' Rationale}

The second profile is the tourism intermediary who tries to consider and reconcile the interests of the consumer and the variables that condition their purchasing decision processes, the supplier and its profitability strategies and the destination territory with the local population and its sustainable development from an environmental, social and economic point of view [155]. This type of manager is open to sustainability as an element of improving its competitiveness through business differentiation in relation to competitors. It is a profile that can respond to any type of intermediary but, above all, affects conventional medium-sized agencies which have a business structure that facilitates the introduction of sustainability practices as a competitive factor [76]. Studies in this area have understood that the commitment of tour operators and travel agencies to sustainability gives them a competitive advantage through added value [156]. Certainly, their proposals are based on a responsible policy, understanding that environmental, socio-cultural, economic and quality aspects must be covered in the definition of where they want to go, how and why [157], with the main purpose of achieving strategic competitiveness and success in the formulation and implementation of value creation from this strategy [158].

In this group of businesses concerned with justifying themselves to their stakeholders, among the methods to increase their competitiveness are seeking the trust of the customers and the improvement of their image in the market, and it is in these businesses where more normative use of the implementation of quality requirement standards and the attainment of quality management system certifications is carried out [113]. Likewise, more and more travel intermediaries give a relevant role to suppliers and, in fact, it is more common for retailers to require certificates or documents proving good practices. It seems to be related to recognizing exemplary corporate behaviors around this issue and being able to identify CSR policies related to those developed in the organization itself.

\subsubsection{Lifestyle and Personal Values}

Lastly, there is a third intermediary profile that fits with the conscientious small entrepreneur, with less symbolic sustainable initiatives and that is more convincing than that of large corporations [15]. They are highly specialized SMEs with a commitment that supports relationships beyond the competitive reinforcement of the company based on win-win acquaintances with destinations, society and the clients themselves [76]. In these businesses, managers' altruist attitudes, further than the appreciation of the benefits for the company, motivate CSR practices, along with their decisions used to be shown and informed due to their understanding of subjective norms, their personal perceptions and their own abilities to be successful [14]. Despite this, the understanding of which role ethics plays in tourism has been largely neglected regarding the function of intermediaries within the tourism supply chain [118]. The results show that smaller intermediaries are more committed to sustainability, which demonstrates that many socio-economic initiatives and certain environmental practices do not necessarily require massive investments (those that only large companies can afford) but rather derive from a different business philosophy, where the personal sense of obligation, the values and the formal engagement of the manager are crucial to adopt CSR policies and measures [114].

A strong belief in values and in the possibility of a change is usually what has led to the creation of these companies, where there is a high degree of commitment acquired by the intermediary and it is consistent with their own ethical principles. In fact, these entrepreneurs often reverse the sense of purpose and the means: sustainability becomes the final objective, while the trip is reduced to the condition to achieve it (tourism is used as a tool to meet sustainable development). The intermediary 
minimizes the commercial component and puts their vocation, values and principles ahead [99]. Similar studies have been based on the assumption that relational networks play an important role in the value chain of the altruistic behavior of tourism brokerage managers, which is key to the development of the company and its partners. If the interaction between businesses is strengthened, factors such as emotion, trust, reliability and reputation become indispensable. In this way, the altruistic behavior of managers plays an important role in creating commercial value [111].

These innovative projects, apart from being of interest to the market, above all, personally satisfy the entrepreneur. The motivation to incorporate sustainability in these business models, represented by small- and medium-sized specialized intermediaries, is especially associated with a personal factor, motivation linked to a vital business project rather than to the search for new markets or economic results in the short term. However, organizations that are committed to sustainability rely on the vital and innovative nature of their project to obtain benefits, to improve their competitiveness and to access new markets, in such a way that the business case also appears, albeit implicitly [76].

\section{Discussion and Conclusions}

Despite the relevance of tour operators and travel agencies in the distribution of tourism products, their role within the supply chain has been scarcely studied, and even less with regard to their performance towards more sustainable practices. In this sense, the development of CSR in these companies seems to be the best way to achieve more responsible goals. After an exhaustive review of the literature, this work has collected the most recent lines of research on tourism intermediaries and CSR, among which the evolution or emergence of current issues, such as online intermediaries, the tourism sustainable supply chain or the underlying managers' motivations in their commitment to sustainability, could be noteworthy. Likewise, throughout this review, various gaps have appeared, for the most part, due to the barely existing literary production which are likely to be studied in future research. In this sense, researchers could delve into the approaches to CSR of very widespread intermediary business models in tourism, such as the franchise and the company associated with a large corporation, the practices in sustainability of OTAs and other new online intermediaries, or the role that each actor in the tourism value chain must assume in order to achieve more responsible tourism.

Most of the research highlights how tourism intermediaries have only just begun to develop CSR policies in their companies, and those that are committed to their implementation mostly opt for actions aimed at the environment, generally because they are the simplest and the most noticeable. However, it seems clear that given its relevant position in the distribution channel, its commitment can be improved highly, beyond the creation and promotion of sustainable tourism products. That is why researchers have pointed out the relevance of the supply chain and the necessary collaboration between all its stakeholders, a very incipient measure in the subsector, where very competitive commercial policies are still being carried out, inherited from market structures that are already distant in time. In connection with this aspect, the studies highlight the innovative nature of CSR as a crucial factor in the survival of these intermediaries, not only in relation to possible internal control and process management measures but also in a clear commitment to the co-creation of value throughout the supply chain. Today more than ever, the use of new technologies and sustainable innovations seems to be the necessary bet for this intermediation sector to be able to overcome the crisis to which the COVID-19 pandemic has led it.

Furthermore, and as in other tourism subsectors, the view on the CSR of the owners and managers of travel intermediary organizations is far from being homogeneous, detecting factors that explain the different views and behaviors. In the first place, it should be noted that corporate factors related to business management processes or the search for markets are also present when explaining the positioning of these companies in their approaches to CSR, but there are other types of factors, such as altruism and lifestyle, which explain more accurately the differences in motivations and behaviors. In this case, altruism has not so much to do with the maturity of the companies in their approach to sustainability as with a personal factor applied to a specific intermediation business model. Altruism as 
an explanatory factor is related to a specific intermediary profile (SME and specialized) but also to the owner profile and, what is quite convincing, with the use of information technologies and social networks.

Author Contributions: Conceptualization, E.I. and L.G.; methodology, E.I. and L.G.; investigation, E.I.; writing —original draft preparation, E.I.; writing—review and editing, L.G. and A.G.; supervision, L.G. and A.G. All authors have read and agreed to the published version of the manuscript.

Funding: This research received no external funding.

Conflicts of Interest: The authors declare no conflict of interest.

\section{References}

1. Alhaddi, H. Triple bottom line and sustainability: A literature review. Bus. Manag. Stud. 2015, 1, 6-10. [CrossRef]

2. Jenkins, H. A critique of conventional CSR theory: An SME perspective. J. Gen. Manag. 2004, 29, 37-57. [CrossRef]

3. Martos, M. Responsabilidad social corporativa y turismo. ¿Realidad o postureo? Tur. Soc. 2018, XXII, 25-44. [CrossRef]

4. Bohdanowicz, P.; Zientara, P. Corporate social responsibility in hospitality: Issues and implications. A case study of Scandic. Scand. J. Hosp. Tour. 2008, 8, 271-293. [CrossRef]

5. Font, X.; Lynes, J. Corporate social responsibility in tourism and hospitality. J. Sustain. Tour. 2018, 26, 1027-1042. [CrossRef]

6. Sheldon, P.J.; Park, S.Y. An exploratory study of corporate social responsibility in the U.S. travel industry. J. Travel Res. 2011, 50, 392-407. [CrossRef]

7. Nicolau, J.L. Corporate social responsibility. Worth-Creating activities. Ann. Tour. Res. 2008, 35, 990-1006. [CrossRef]

8. Buhalis, D.; Law, R. Progress in information technology and tourism management: 20 years on and 10 years after the Internet. The state of eTourism research. Tour. Manag. 2008, 29, 609-623. [CrossRef]

9. Khairat, G.; Maher, A. Integrating sustainability into tour operator business: An innovative approach in sustainable tourism. Tourismos 2012, 7, 213-233.

10. Sigala, M. A supply chain management approach for investigating the role of tour operators on sustainable tourism: The case of TUI. J. Clean. Prod. 2008, 16, 1589-1599. [CrossRef]

11. European Commission. Preferences of Europeans Towards Tourism. Eurobarometer No 432; Directorate-General for Communication: Brussels, Belgium, 2016.

12. Rivera, J.; Pastor, R. ¿Hacia un turismo más sostenible tras el COVID-19? Percepción de las agencias de viajes españolas. Gran Tour Rev. Investig. Tur. 2020, 21, 206-229.

13. Lund-Durlacher, D. Corporate social responsibility and tourism. In Education for Sustainability in Tourism-A Handbook of Processes, Resources, and Strategies; Moscardo, P., Benckendorff, G., Eds.; Springer: Berlin/Heidelberg, Germany, 2015; pp. 59-72.

14. Lin, L.P.L.; Yu, C.Y.; Chang, F.C. Determinants of CSER practices for reducing greenhouse gas emissions: From the perspectives of administrative managers in tour operators. Tour. Manag. 2018, 64, 1-12. [CrossRef]

15. Tixier, M. Will sustainable management be a clear differentiator for tour operators? Int. J. Tour. Hosp. Res. 2009, 20, 461-466. [CrossRef]

16. Wells, V.K.; Manika, D.; Gregory-Smith, D.; Taheri, B.; McCowlen, C. Heritage tourism, CSR and the role of employee environmental behaviour. Tour. Manag. 2015, 48, 399-413. [CrossRef]

17. Coles, T.; Fenclova, E.; Dinan, C. Tourism and corporate social responsibility: A critical review and research agenda. Tour. Manag. Perspect. 2013, 6, 122-141. [CrossRef]

18. Runfola, A.; Rosati, M.; Guercini, S. New Business Models in Online Hotel Distribution: Emerging Private Sales versus Leading IDS. Serv. Bus. 2013, 7, 183-205. [CrossRef]

19. Standing, C.; Tang-Taye, J.P.; Boyer, M. The Impact of the Internet in Travel and Tourism: A Research Review 2001. J. Travel Tour. Mark. 2014, 31, 82-113. [CrossRef]

20. Pastor, R.; Rivera, J. Airbnb and tourism intermediation. Competition or coopetition? The perception of travel agents in Spain. Empres. Humanismo 2020, XXIII, 107-132. [CrossRef] 
21. Camisón, C.; Monfort-Mir, V.M. Measuring innovation in tourism from schumpeterian and the dynamic-Capabilities perspectives. Tour. Manag. 2012, 33, 776-789. [CrossRef]

22. Mei, X.Y.; Arcodia, C.; Ruhanen, L. Towards tourism innovation: A critical review of public policies at the national level. Tour. Manag. Perspect. 2012, 4, 92-105. [CrossRef]

23. Derevianko, O. Reputation stability vs anti-crisis sustainability: Under what circumstances will innovations, media activities and CSR be in higher demand? Oeconomia Copernic. 2019, 10, 511-536. [CrossRef]

24. Higgins-Desbiolles, F. Socialising tourism for social and ecological justice after COVID. Tour. Geogr. 2020, 1-14. [CrossRef]

25. Gössling, S.; Scott, D.; Hall, C.M. Pandemics, tourism and global change: A rapid assessment of COVID. J. Sustain. Tour. 2020, 48-52. [CrossRef]

26. Garay, L. El sector empresarial turístico como agente de desarrollo económico. In Cooperación en Turismo. Nuevos Desafíos, Nuevos Debates; Universitat Oberta de Catalunya-Laboratori del Nou Turisme; Universitat de Barcelona: Barcelona, Spain, 2013; pp. 307-328.

27. Peña, D.D.; Guevara, A.; Fraiz, J.A. La investigación de la responsabilidad social empresarial en el sector hotelero. Análisis y revisión de la literatura científica. Tur. Soc. 2016, 18, 137-158.

28. Buckley, R. Sustainable tourism: Research and reality. Ann. Tour. Res. 2012, 39, 528-546. [CrossRef]

29. Font, X.; Walmsley, A.; Cogotti, S.; Mccombes, L.; Häusler, N. Corporate social responsibility: The disclosure-performance gap. Tour. Manag. 2012, 33, 1544-1553. [CrossRef]

30. Farrington, T.; Curran, R.; Gori, K.; O'Gorman, K.D.; Queenan, C.J. Corporate social responsibility: Reviewed, rated, revised. Int. J. Contemp. Hosp. Manag. 2017, 29, 30-47. [CrossRef]

31. Inoue, Y.; Lee, S. Effects of different dimensions of corporate social responsibility on corporate financial performance in tourism-related industries. Tour. Manag. 2011, 32, 790-804. [CrossRef]

32. De Grosbois, D. Corporate social responsibility reporting by the global hotel industry: Commitment, initiatives and performance. Int. J. Hosp. Manag. 2012, 31, 896-905. [CrossRef]

33. Pope, S.; Wæraas, A. CSR-washing is rare: A conceptual framework, literature review, and critique. J. Bus. Ethics 2015, 137, 173-193. [CrossRef]

34. Kang, K.H.; Lee, S.; Huh, C. Impacts of positive and negative corporate social responsibility activities on company performance in the hospitality industry. Int. J. Hosp. Manag. 2010, 29, 72-82. [CrossRef]

35. Flores, D.; Barroso, M.O.; Castro, N.J. Reflexiones teóricas sobre el análisis de la responsabilidad social en el sector turístico. Rev. Estud. Empres. Segunda Epoca 2016, 2, 5-16. [CrossRef]

36. Fernández, M.T.; Cuadrado, R. La responsabilidad social empresarial en el sector hotelero: Revisión de la literatura científica. Cuad. Tur. 2011, 28, 47-57.

37. Ayuso, S. Adoption of voluntary environmental tools for sustainable tourism: Analysing the experience of Spanish hotels. Corp. Soc. Responsib. Environ. Manag. 2006, 13, 207-220. [CrossRef]

38. Budeanu, A.; Miller, G.; Moscardo, G.; Ooi, C.S. Sustainable tourism, progress, challenges and opportunities: An introduction. J. Clean. Prod. 2016, 111, 285-294. [CrossRef]

39. Horng, J.S.; Hsu, H.; Tsai, C.Y. An assessment model of corporate social responsibility practice in the tourism industry. J. Sustain. Tour. 2018, 26, 1085-1104. [CrossRef]

40. Rodríguez, J.M.; Alonso, M.M.; Celemín, M.S. Responsabilidad social corporativa en las cadenas hoteleras españolas: Un estudio de casos. Rev. Responsab. Soc. Empres 2013, 13, 15-50.

41. Font, X.; Guix, M.; Bonilla-Priego, M.J. Corporate social responsibility in cruising: Using materiality análisis to create shared value. Tour. Manag. 2016, 53, 175-186. [CrossRef]

42. Bramwell, B.; Higham, J.; Lane, B.; Miller, G. Twenty-five years of sustainable tourism and the journal of sustainable tourism: Looking back and moving forward. J. Sustain. Tour. 2017, 25, 1-9. [CrossRef]

43. Álvarez, A.; Rego, G.; Leira, J.; Gomis, A.; Caramés, R.; Andrade, M.J. La responsabilidad social corporativa como oportunidad para las empresas turísticas. Rotur 2009, 2, 11-43. [CrossRef]

44. Garzón, M.A.; Pérez, L.A. Consideraciones para el código de ética empresarial de las empresas afiliadas a la AMAV-México. Orinoquia 2016, 20, 87-101. [CrossRef]

45. Yaman, H.R.; Gurel, E. Ethical ideologies of tourism marketers. Ann. Tour. Res. 2006, 33, 470-489. [CrossRef]

46. Schilcher, D. Growth versus equity: The continuum of pro-poor tourism and neoliberal governance. Curr. Issues Tour. 2007, 10, 166-193. [CrossRef] 
47. Anderson, L.; Mastrangelo, C.; Chase, L.; Kestenbaum, D.; Kolodinsky, J. Eco-labeling motorcoach operators in the North American travel tour industry: Analyzing the role of tour operators. J. Sustain. Tour. 2013, 21,750-764. [CrossRef]

48. Borden, D.S.; Coles, T.; Shaw, G. Social marketing, sustainable tourism, and small/medium size tourism enterprises: Challenges and opportunities for changing guest behaviour. J. Sustain. Tour. 2017, 25, 903-920. [CrossRef]

49. Gao, J.; Huang, Z.; Zhang, C. Tourists' perceptions of responsibility: An application of norm-activation theory. J. Sustain. Tour. 2017, 25, 276-291. [CrossRef]

50. Liu, M.T.; Wong, I.A.; Rongwei, C.; Tseng, T.H. Do perceived CSR initiatives enhance customer preference and loyalty in casinos? Int. J. Contemp. Hosp. Manag. 2014, 26, 1024-1045.

51. Park, S.Y.; Levy, S.E. Corporate social responsibility: Perspectives of hotel frontline employees. Int. J. Contemp. Hosp. Manag. 2014, 26, 332-348. [CrossRef]

52. Littell, J.H.; Corcoran, J.; Pillai, V. Systematic Reviews and Meta-Analysis; Oxford University Press: New York, NY, USA, 2008.

53. Tranfield, D.; Denyer, D.; Smart, P. Towards a methodology for developing evidence-informed management knowledge by means of systematic review. Br. J. Manag. 2003, 14, 207-222. [CrossRef]

54. Schwartz, K.; Tapper, R.; Font, X. A sustainable supply chain management framework for tour operators. J. Sustain. Tour. 2008, 16, 298-314. [CrossRef]

55. Lacalle, L. Agencias de viajes en España. Una industria convulsa. Pap. Tur. 2013, 54, 122-138.

56. Flores, D.; Salazar, L.; Santana, M.Á. ¿Desaparecerán los tour operadores? El papel de los intermediarios en la distribución turística: Análisis del caso de Tenerife. PASOS Rev. Tur. Patrim. Cult. 2011, 9, 341-351.

57. Pastor, R. Las Agencias de Viajes Tradicionales en España Frente al Reto de la Nueva Intermediación. Nuevas Formas de Relación con Clientes y Proveedores; Universidad Rey Juan Carlos: Madrid, Spain, 2019.

58. Udayasankar, K. Corporate social responsibility and firm size. J. Bus. Ethics 2008, 83, 167-175. [CrossRef]

59. Zapata, M.J.; Hall, C.M.; Backlund, S. Can MNCs promote more inclusive tourism? Apollo tour operator's sustainability work. Tour. Geogr. 2018, 20, 630-652. [CrossRef]

60. Richards, P.; Font, X. Sustainability in the tour operator-ground agent supply chain. J. Sustain. Tour. 2019, 27, 277-291. [CrossRef]

61. Tiigu, G.; Popescu, D.; Hornoiu, R.I. Corporate social responsibility-An European approach through the tourism SME's perspectives. Amfiteatru Econ. J. 2016, 18, 742-756.

62. Budeanu, A. Exploring organizational antecedents for sustainable product development for international tour operating businesses. CLCS Work. Pap. Ser. 2012, 9, 1-24.

63. Goodwin, H. Responsible Tourism: Using Tourism for Sustainable Development, 2nd ed.; Goodfellow: Oxford, UK, 2016.

64. Font, X.; Elgammal, I.; Lamond, I. Greenhushing: The deliberate under communicating of sustainability practices by tourism businesses. J. Sustain. Tour. 2017, 25, 1007-1023. [CrossRef]

65. Villarino, J.; Font, X. Sustainability marketing myopia: The lack of persuasiveness in sustainability communication. J. Vacat. Mark. 2015, 21, 326-335. [CrossRef]

66. Dolnicar, S.; Laesser, C. Travel agency marketing strategy: Insights from Switzerland. J. Travel Res. 2007, 46, 133-146. [CrossRef]

67. McKercher, B.; Mak, B.; Wong, S. Does climate change matter to the travel trade? J. Sustain. Tour. 2014, 22, 685-704. [CrossRef]

68. Chen, A.; Peng, N. Recommending green hotels to travel agencies' customers. Ann. Tour. Res. 2014, 48, $284-289$. [CrossRef]

69. Alonso, M.M.; Bagur, L.; Llach, J. The adoption of quality management practices and their impact on business performance in small service companies: The case of Spanish travel agencies. Serv. Bus. 2015, 9, 57-75.

70. Xin, T.K.; Chan, J.K.L. Tour operator perspectives on responsible tourism indicators of Kinabalu National Park, Sabah. Procedia Soc. Behav. Sci. 2014, 144, 25-34. [CrossRef]

71. Jenkins, H. A 'business opportunity' model of corporate social responsibility for small- and medium-sized enterprises. Bus. Ethics A Eur. Rev. 2009, 18, 21-36. [CrossRef]

72. Chubchuwong, M. The impact of CSR satisfaction on destination loyalty: A study of MICE travelers in Thailand. Asia Pac. J. Tour. Res. 2019, 24, 168-179. [CrossRef] 
73. Garay, L.; Gomis, J.M.; González, F. Management, altruism, and customer focus as drivers of corporate social responsibility in tourism intermediation. Tour. Anal. 2017, 22, 255-260. [CrossRef]

74. Van Wijk, J.; Persoon, W. A long-haul destination: Sustainability reporting among tour operators. Eur. Manag. J. 2006, 24, 381-395.

75. Norbit, N.; Nawawi, A.; Salin, P.; Azlin, A.S. Corporate social responsibility practices among the smes in Malaysia-A preliminary analysis. Manag. Account. Rev. 2017, 16, 17-40. [CrossRef]

76. Garay, L.; Gomis, J.M.; González, F. El valor de la sostenibilidad como factor de diferenciación en los procesos de intermediación turística: Un análisis para el caso de las pymes catalanas. Cuad. Tur. 2018, 41, 219-248. [CrossRef]

77. Tapper, R. Tourism and socio-economic development: UK tour operators' business approaches in the context of the new international agenda. Int. J. Tour. Res. 2001, 3, 351-366. [CrossRef]

78. Carey, S.; Gountas, Y.; Gilbert, D. Tour operators and destination sustainability. Tour. Manag. 1997, 18, $425-431$. [CrossRef]

79. Kilipiris, F.; Zardava, S. Developing sustainable tourism in a changing environment: Issues for the tourism enterprises (travel agencies and hospitality enterprises). Procedia Soc. Behav. Sci. 2012, 44, 44-52. [CrossRef]

80. Budeanu, A. Environmental supply chain management in tourism: The case of large tour operators. J. Clean. Prod. 2009, 17, 1385-1392.

81. Clarke, J. A synthesis of activity towards the implementation of sustainable tourism: Ecotourism in a different context. Int. J. Sustain. Dev. 2002, 5, 232-250. [CrossRef]

82. Salvado, J. Travel experience ecosystem model. Building travel agencies' business resilience in Portugal. Eur. J. Tour. Hosp. Recreat. 2011, 2, 95-116.

83. Russo, A.; Tencati, A. Formal vs. informal CSR strategies: Evidence from Italian micro, small, medium- sized, and large firms. J. Bus. Ethics 2009, 85, 339-353. [CrossRef]

84. Sardianou, E.; Kostakis, I.; Mitoula, R.; Gkaragkani, V.; Lalioti, E.; Theodoropoulou, E. Understanding the entrepreneurs' behavioural intentions towards sustainable tourism: A case study from Greece. Environ. Dev. Sustain. 2016, 18, 857-879. [CrossRef]

85. Panda, S.; Modak, N.M. Exploring the effects of social responsibility on coordination and profit division in a supply chain. J. Clean. Prod. 2016, 139, 25-40. [CrossRef]

86. He, P.; He, Y.; Xu, H.; Zhou, L. Online selling mode choice and pricing in an $\mathrm{O} 2 \mathrm{O}$ tourism supply chain considering corporate social responsibility. Electron. Commer. Res. Appl. 2019, 38, 100894. [CrossRef]

87. Chunjou, M.; Pang, S.F.H. An exploratory study of corporate social responsibility of travel agency websites and consumers' low carbon travel intention. In Proceedings of the 2013 7th International Conference on Complex, Intelligent, and Software Intensive Systems, CISIS 2013, Taichung, Taiwan, 3-5 July 2013; IEEE: Piscataway, NJ, USA, 2013; pp. 661-666.

88. Lozano, J.; Arbulú, I.; Rey-Maquieira, J. The greening role of tour operators. Environ. Manag. 2016, 57, 49-61. [CrossRef] [PubMed]

89. Dube, K.; Nhamo, G. Greenhouse gas emissions and sustainability in Victoria Falls: Focus on hotels, tour operators and related attractions. Afr. Geogr. Rev. 2020, 1-16. [CrossRef]

90. Alonso, M.M.; Bagur, L.; Llach, J.; Perramon, J. Sustainability in small tourist businesses: The link between initiatives and performance. Curr. Issues Tour. 2018, 21, 1-20. [CrossRef]

91. Ioncică, M.; Petrescu, E.C.; Ioncică, D.E. Innovations in selling tourism products and their impact on the efficiency of the activity of travel agencies and sustainability. Int. J. Econ. Pract. Theor. 2015, 5, 495-502.

92. Ko, W.W.J.; Liu, G.; Ngugi, I.K.; Chapleo, C. External supply chain flexibility and product innovation performance: A study of small- and medium-sized UK-based manufacturers. Eur. J. Mark. 2018, 52, 1981-2004. [CrossRef]

93. Kraesgenberg, A.L.; Beldad, A.D.; Hegner, S.M. The impact of corporate social responsibility (CSR) program type, crisis response strategy, and crisis type on postcrisis consumer trust and purchase intention. In Creating Marketing Magic and Innovative Future Marketing Trends; Springer: Cham, Switzerland, 2017; pp. 673-677.

94. Balaguer, M.R. Propuestas de la responsabilidad social corporativa en un contexto de crisis financiera internacional. Prism. Soc. 2013, 10, 157-190.

95. Thomas, R.; Shaw, G.; Page, S.J. Understanding small firms in tourism: A perspective on research trends and challenges. Tour. Manag. 2011, 32, 963-976. [CrossRef] 
96. Almunawar, M.N.; Anshari, M.; Susanto, H. Crafting strategies for sustainability: How travel agents should react in facing a disintermediation. Oper. Res. 2013, 13, 317-342. [CrossRef]

97. Mourshed, M.M.; Matipa, W.M.; Keane, M.; Kelliher, D. Towards interoperability: ICT in academic curricula for sustainable construction. In Proceedings of the CIB W107 1st International Conference: Creating a Sustainable Construction Industry in Developing Countries, CIB Publications, Ottawa, ON, Canada, 1 March 2000; pp. 11-13. [CrossRef]

98. Alegre, J.; Sard, M. When demand drops and prices rise. Tourist packages in the balearic islands during the economic crisis. Tour. Manag. 2015, 46, 375-385. [CrossRef]

99. Chapuis, L. Análisis Argumentativo del Discurso de las Agencias de Viaje Expertas en Turismo Sostenible; Universidad de Sevilla: Sevilla, Spain, 2013; pp. 87-107.

100. Huët, R. Quand les chefs d'entreprise célèbrent leurs engagements ethiques. Étude de la symbolique des cérémonies publiques de signature des chartes. Commun. Inf. Médias Théories Prat. 2011, 28. [CrossRef]

101. Baniya, R.; Thapa, B.; Kim, M.S. Corporate social responsibility among travel and tour operators in Nepal. Sustainability 2019, 11, 2771. [CrossRef]

102. Xu, X.; Gursoy, D. Motivators and inhibitors of implementing sustainable hospitality supply chain management. In Collaboration in Tourism Businesses and Destinations: A Handbook; Emerald: London, UK, 2015; pp. 299-320.

103. Mwesiumo, D.; Halpern, N. Acquiescence and conflict in exchanges between inbound tour operators and their overseas outbound partners: A case study on Tanzania. Tour. Manag. 2018, 69, 345-355. [CrossRef]

104. Tsaur, S.H.; Yung, C.Y.; Lin, J.H. The relational behavior between wholesaler and retailer travel agencies: Evidence from Taiwan. J. Hosp. Tour. Res. 2006, 30, 333-353. [CrossRef]

105. Baddeley, J.; Font, X. Sustainability, health and safety, or quality? Tour operator supply chain management under scrutiny. Tour. Recreat. Res. 2011, 44, 1-23.

106. Allen, M.W.; Walker, K.L.; Brady, R. Sustainability discourse within a supply chain relationship: Mapping convergence and divergence. J. Bus. Commun. 2012, 49, 210-236. [CrossRef]

107. Brockhaus, S.; Kersten, W.; Knemeyer, A.M. Where do we go from here? Progressing sustainability implementation efforts across supply chains. J. Bus. Logist. 2013, 34, 167-182. [CrossRef]

108. Font, X.; Tapper, R.; Schwartz, K.; Kornilaki, M. Sustainable supply chain management in tourism. Bus. Strateg. Environ. 2008, 17, 260-271. [CrossRef]

109. Kwon, I.W.G.; Suh, T. Trust, commitment and relationships in supply chain management: A path analysis. Supply Chain Manag. Int. J. 2005, 10, 26-33. [CrossRef]

110. Piboonrungroj, P.; Disney, S.M. Supply chain collaboration in tourism: A transaction cost economics analysis. Int. J. Supply Chain Manag. 2015, 4, 25-31.

111. Cheng, M.L.; Liu, T.H.; Lin, C.C. Case study of altruistic behavior and relational network with business value on local travel agencies. J. Res. Bus. Econ. Manag. 2017, 8, 1455-1464.

112. Okech, R.N. The role of tour operators in sustainable ecotourism: Lessons from Kenya. Tour. Today 2004, 4, 78-88.

113. Font, X.; Garay, L.; Jones, S. Sustainability motivations and practices in small tourism enterprises in european protected areas. J. Clean. Prod. 2016, 137, 1439-1448. [CrossRef]

114. Goffi, G.; Masiero, L.; Pencarelli, T. Rethinking sustainability in the tour-operating industry: Worldwide survey of current attitudes and behaviors. J. Clean. Prod. 2018, 183, 172-182. [CrossRef]

115. Atanase, A.; Schileru, I. Quality and vision in the Romanian tourism agencies. Amfiteatru Econ. 2014, 16, 1075-1088.

116. Wong, J.Y.; Lee, W.H. Leadership through service: An exploratory study of the leadership styles of tour leaders. Tour. Manag. 2012, 33, 1112-1121. [CrossRef]

117. Erdogan, N. Environmental views and practices in tourism industry: A study on travel agency managers. J. Bus. Res. 2012, 4, 52-65.

118. Mossaz, A.; Coghlan, A. The role of travel agents' ethical concerns when brokering information in the marketing and sale of sustainable tourism. J. Sustain. Tour. 2017, 261. [CrossRef]

119. Theodosiou, M.; Katsikea, E. Antecedents and performance of electronic business adoption in the hotel industry. Eur. J. Mark. 2012, 46, 258-283. [CrossRef]

120. Buhalis, D.; Jun, S.H. E-tourism. CTR Contemp. Tour. Rev. 2011, 1, 2-38.

121. Asongu, J. Innovation as an argument for corporate social responsibility. J. Bus. Public Policy 2007, 1, 1-21. 
122. Gössling, S.; Buckley, R. Carbon labels in tourism: Persuasive communication? J. Clean. Prod. 2016, 111, 358-369. [CrossRef]

123. Wehrli, R.; Priskin, J.; Demarmels, S.; Schaffner, D.; Schwarz, J.; Truniger, F.; Stettler, J. How to communicate sustainable tourism products to customers: Results from a choice experiment. Curr. Issues Tour. 2017, 20, 1375-1394. [CrossRef]

124. Law, R.; Leung, R.; Lo, A.; Leung, D.; Fong, L.H.N. Distribution channel in hospitality and tourism. Revisiting disintermediation from the perspectives of hotels and travel agencies. Int. J. Contemp. Hosp. Manag. 2015, 27, 431-452. [CrossRef]

125. Garay, L.; Font, X. Corporate social responsibility in tourism small and medium enterprises evidence from Europe and Latin America. Tour. Manag. Perspect. 2013, 7, 38-46.

126. Komppula, R. Developing the quality of a tourist experience product in the case of nature based activity services. Scand. J. Hosp. Tour. 2006, 6, 136-149. [CrossRef]

127. Luck, M. The "New Environmental Paradigm": Is the scale of Dunlap and Van Liere applicable in a tourism context? Tour. Geogr. 2002, 5, 228-240. [CrossRef]

128. Aguiar, T.; Moreno, S.; Picazo, P. How could traditional travel agencies improve their competitiveness and survive? A qualitative study in Spain. Tour. Manag. Perspect. 2016, 20, 98-108.

129. Berné, C.; García-González, M.; García-Uceda, E.; Múgica, M. Modelización de los cambios en el sistema de distribución del sector turístico debidos a la incorporación de las tecnologías. Cuad. Econ. Dir. Empres. 2012, 15, 117-129. [CrossRef]

130. Crane, A.; Matten, D. Business Ethics: Managing Corporate Citizenship and Sustainability in the Age of Globalization, 3rd ed.; Oxford University Press: New York, NY, USA, 2016.

131. Frosio, G.F. Why keep a dog and bark yourself? From intermediary liability to responsibility. Int. J. Law Inf. Technol. 2018, 26, 1-33. [CrossRef]

132. Inversini, A.; Masiero, L. Selling rooms online: The use of social media and online travel agents. Int. J. Contemp. Hosp. Manag. 2014, 26, 272-292. [CrossRef]

133. Wang, C.; Leng, M.; Liang, L. Choosing an online retail channel for a manufacturer: Direct sales or consignment? Int. J. Prod. Econ. 2018, 195, 338-358. [CrossRef]

134. Del Chiappa, G.; Zara, A. Offline versus online intermediation: A study of booking behavior of tourists travelling to Sardinia. In Information and Communication Technologies in Tourism, ENTER Proceedings of the International Conference in Lugano, Switzerland; Springer: Cham, Switzerland, 2015; pp. 709-721.

135. Kaewkitipong, L. Disintermediation in the tourism industry: An investigation of Thai tourism SMEs. Int. J. Electron. Bus. 2011, 9, 516-535. [CrossRef]

136. Rodríguez, A.; Pastor, R.; Fernández-Villarán, M.A. Evolución de la intermediación turística en España tras la aparición de las TIC en el sector. Rev. Empres. Humanismo 2017, XX, 87-106. [CrossRef]

137. Agag, G.M.; El-Masry, A.A. Why do consumers trust online travel websites? Drivers and outcomes of consumer trust toward online travel websites. J. Travel Res. 2017, 56, 347-369. [CrossRef]

138. Min, S.R.; Lee, S.M. A study on the behavior of the user according to the distribution development of online travel agency. J. Distrib. Sci. 2020, 18, 25-35.

139. Van der Duim, R.; van Marwijk, R. The implementation of an environmental management system for Dutch tour operators: An actor-network perspective. J. Sustain. Tour. 2006, 14, 449-472. [CrossRef]

140. Bastakis, C.; Buhalis, D.; Butler, R.W. The perception of small and medium sized tourism accommodation providers on the impacts of the tour operators' power in Eastern Mediterranean. Tour. Manag. 2004, 25, 151-170. [CrossRef]

141. Medina, R.D.; Medina, D.; García, J.M. Understanding European tour operators' control on accommodation companies: An empirical evidence. Tour. Manag. 2003, 24, 135-147. [CrossRef]

142. Cho, M.; Bonn, M.A.; Giunipero, L.; Jaggi, J.S. Contingent effects of close relationships with suppliers upon independent restaurant product development: A social capital perspective. Int. J. Hosp. Manag. 2017, 67, 154-162. [CrossRef]

143. Xu, X.; Gursoy, D. Influence of sustainable hospitality supply chain management on customers' attitudes and behaviors. Int. J. Hosp. Manag. 2015, 49, 105-116. [CrossRef]

144. Worthington, I.; Ram, M.; Jones, T. 'Giving something back': A study of corporate social responsibility in UK South Asian small enterprises. Bus. Ethics A Eur. Rev. 2006, 15, 95-108. [CrossRef] 
145. Condon, L. Sustainability and small to medium sized enterprises-How to engage them. Aust. J. Environ. Educ. 2004, 20, 57-67. [CrossRef]

146. Harness, D.; Ranaweera, C.; Karjaluoto, H.; Jayawardhena, C. The role of negative and positive forms of power in supporting CSR alignment and commitment between large firms and SMEs. Ind. Mark. Manag. 2018, 75, 17-30. [CrossRef]

147. Perrini, F. SMEs and CSR theory: Evidence and implications from an Italian perspective. J. Bus. Ethics 2006, 67, 305-316. [CrossRef]

148. Bagur, L.; Perramon, J.; Amat, O. Impact of quality and environmental investment on business competitiveness and profitability in small service business: The case of travel agencies. Total Qual. Manag. Bus. Excell. 2015, 26, 840-853. [CrossRef]

149. Alonso, M.M.; Rodríguez, J.M.; Rubio, L. Reasons for implementing certified quality systems and impact on performance: An analysis of the hotel industry. Serv. Ind. J. 2012, 32, 919-936. [CrossRef]

150. Bagur, L.; Llach, J.; Alonso, M.M. Is the adoption of environmental practices a strategic decision for small service companies? An empirical approach. Manag. Decis. 2013, 51, 41-62. [CrossRef]

151. Llach, J.; Perramon, J.; Alonso, M.M.; Bagur, L. Joint impact of quality and environmental practices on firm performance in small service businesses: An empirical study of restaurants. J. Clean. Prod. 2013, 44, 96-104. [CrossRef]

152. Bernal, J.A.; Briones, A.J.; de Nieves, C. Impacts of the CSR strategies of technology companies on performance and competitiveness. Tour. Manag. Stud. 2017, 13, 73-81. [CrossRef]

153. Pozo, H.; Tachizawa, T. Marketing and social responsibility: An exploratory study of local tourism. Tour. Mang. Stud. 2018, 14, 39-49. [CrossRef]

154. Dervitsiotis, K.N. An innovation-based approach for coping with increasing complexity in the global economy. Total Qual. Manag. Bus. Excell. 2012, 23, 997-1011. [CrossRef]

155. Waligo, V.M.; Clarke, J.; Hawkins, R. Implementing sustainable tourism: A multi-stakeholder involvement management framework. Tour. Manag. 2013, 36, 342-353. [CrossRef]

156. Goodwin, H.; Francis, J. Ethical and responsible tourism: Consumer trends in the UK. J. Vacat. Mark. 2003, 9, 271-284. [CrossRef]

157. Castro, L.D.; Ramírez, L.P.; Rodríguez, L.V.; Sierra, L.C.; Torres, S.C.; Torres, L.M. Servi Travel Ltda. A management proposal to improve its competitiveness and sustainability in the tourism sector. Tur. Soc. 2016, 19, 193-212.

158. Hitt, A.; Duane, R.; Hoskisson, R. Administración Estratégica: Competitividad y Globalización. Conceptos y Casos; Cengage Learning EMEA: Bogotá, Colombia, 2008.

Publisher's Note: MDPI stays neutral with regard to jurisdictional claims in published maps and institutional affiliations.

(C) 2020 by the authors. Licensee MDPI, Basel, Switzerland. This article is an open access article distributed under the terms and conditions of the Creative Commons Attribution (CC BY) license (http://creativecommons.org/licenses/by/4.0/). 